\title{
Censura não é educação
}

\author{
Maria Cristina Castilho Costa \\ Professora livre-docente do Departamento de Comunicações e Artes da \\ Escola de Comunicações e Artes da Universidade de São Paulo e \\ editora da revista Comunicação \& Educação. \\ E-mail: criscast@usp.br
}

Resumo: Este texto analisa a censura a partir de acontecimentos recentes ocorridos no mundo todo e também no Brasil, obrigando-nos a pensar sobre como age a censura instituída como poder público. Com base na pesquisa realizada no Arquivo Miroel Silveira, da Escola de Comunicações e Artes da USP, a autora demonstra como se procedia à censura prévia de peças teatrais no Estado de São Paulo, entre 1930 e 1970, e sustenta que só a educação pode garantir a defesa do público e o combate aos abusos na arte e nos meios de comunicação.

Palavras-chave: censura, meios de comunicação, teatro, educação, cidadania.
Abstract: This paper analyzes censorship by focusing recent happenings in Brazil and abroad, compelling us to think on the dynamics of censorship established by the government. Based on the research that takes place on the Archive Miroel Silveira, of the Escola de Comunicações e Artes of Universidade de São Paulo, the author shows how previous censorship to theater plays was made in the Sao Paulo State between 1930 and 1970. She defends the idea that only education can guarantee the audience protection and the fight against abuses in art and communication.

Keywords: censorship, media, theater, education, citizenship.

Em 2005, uma série de 12 charges publicadas no jornal dinamarquês Jyllands-Posten causaram grande celeuma no mundo todo por se tratarem de sátiras envolvendo o profeta Maomé. Numa delas ele era mostrado pedindo aos terroristas islâmicos que não mais se matassem, pois já não havia virgens disponíveis no paraíso. Em outra, o profeta aparecia com um turbante em forma de bomba.

Consideradas ofensivas por líderes e associações muçulmanas, as charges foram condenadas por fazer menção desrespeitosa ao líder religioso e por apresentá-lo de forma antropomórfica, o que é proibido pela religião islâmica. Imediatamente, estabeleceu-se um grande debate opondo-se o direito à liberdade de expressão, valor inquestionável do Ocidente, ao respeito ao pluralismo e às diferenças culturais e religiosas. Diversos jornais, inclusive na França, republicaram as caricaturas de Maomé, enquanto outros, e até mesmo sites na internet, acatavam o conselho de não ofender as autoridades muçulmanas. Houve sanções comerciais de países árabes aos europeus, além de ações judiciais contra o jornal dinamarquês. $\mathrm{O}$ conflito chegou às ruas e mortes ocorreram, com baixas entre os manifestantes dos dois lados do conflito. Governos europeus procuraram acalmar os ânimos e sustentar que não cabia a eles proibir a publicação das

Recebido: 15/01/2008 Aprovado: 18/02/2008 
1. Disponivel em: $<$ http://www.bbc.co.uk/ portuguese/noticias/ story/2006/02/060208 chiracchargescl.shtml>. Acesso em: 08/02/2006.

2. <http://www.observatoriodaimprensa.com. $\mathrm{br} / \mathrm{s}$. imagens, garantindo-se a liberdade da imprensa, mas colocaram-se em defesa de uma atitude de respeito e moderação, chamada de cooperação pacífica, como o primeiro-ministro dinamarquês, Anders Rasmussen. Segundo ele, "esses eventos ressaltaram a importância de combinar a liberdade de expressão com o respeito por crenças religiosas"'.

Com menor repercussão, acontecimentos semelhantes continuaram a alimentar o debate sobre os limites entre liberdade de expressão e respeito aos direitos individuais. Em 2006, bispos da Bavária tentaram impedir a exibição da série animada Popetown, veiculada pela Divisão Alemã da MTV, por considerarem que ela satirizava e desrespeitava o Papa. A corte alemã, entretanto, assim como os órgãos reguladores do setor, não julgou procedente o pedido e a série foi transmitida, sob protestos dos bispos. Já em 2007, o site Observatório da Imprensa $^{2}$ divulgou que uma imagem do Papa, apresentando-o como transexual, foi retirada de uma exposição de arte em Milão por ter sido considerada uma blasfêmia. Nesse caso, diversas entidades italianas ponderaram que os direitos dos cidadãos haviam sido violados.

\section{A DISCUSSÃO SOBRE A CENSURA NO BRASIL}

No Brasil, também, acontecimentos semelhantes opondo defensores da liberdade de expressão e defensores dos direitos individuais insuflaram esse debate. Em 2005, o escritor Fernando Morais teve seu livro Na toca dos leões retirado das livrarias por decisão judicial, que acatou ação movida pelo deputado Ronaldo Caiado, presidente da UDR - União Democrática Ruralista, o qual afirmou serem falsas as declarações a ele atribuídas pelo autor na obra. O juiz goiano Jeová Sardinha de Morais proibiu também em sua sentença que Fernando Morais ou a editora Planeta se manifestassem publicamente sobre o fato, cabendo-lhes uma multa de $\mathrm{R} \$ 5.000,00$ (cinco mil reais) a cada desobediência cometida. Associações de imprensa e jornalistas levantaram-se contra o arbítrio que, segundo eles, substituía a censura fardada pela togada.

Em 2007, repetiu-se o fato. O cantor e compositor Roberto Carlos moveu uma ação judicial contra a biografia escrita por Paulo Cesar Araújo, Roberto Carlos em detalhe, por considerá-la ofensiva à sua reputação. O juiz Tércio Pires acatou os argumentos dos advogados do cantor e o livro foi proibido. Novamente, a editora Planeta foi alvo da decisão judicial e resolveu entrar em acordo com o reclamante - os livros foram retirados das livrarias, embora cópias piratas já circulassem pela internet.

O caso mais recente de proibição foi contra o desfile de um carro alegórico da escola de samba Viradouro, o qual fazia alusão ao Holocausto, no Carnaval de 2008. O advogado da Federação Israelita do Rio de Janeiro, Ricardo Brajterman, justificou a ação judicial por ter conhecimento de que a alegoria faria menção ao Holocausto através de esculturas representando corpos empilhados, em alusão aos judeus mortos pelo regime nazista. A justiça deu ganho de causa 
à Federação, e a Viradouro, na última hora, substituiu a alegoria por outra com figuras amordaçadas, numa crítica contundente à violação da liberdade de expressão. Segundo a juíza que deu a sentença, o Carnaval não é espaço para se falar de barbáries como o Holocausto.

Embora cada exemplo tenha suas peculiaridades e diferentes interesses em jogo, não há dúvida de que levantam uma questão importante - a legitimidade ou não da censura e os limites que envolvem o direito à informação e à liberdade de expressão. As discussões que vêem sendo travadas nos últimos anos não são relativas apenas a esses acontecimentos mais polêmicos, mas às relações cotidianas entre os poderes instituídos e os órgãos de divulgação públicos e privados. Em 2007, o governo federal brasileiro apresentou projeto de lei que tornava mais rígido o controle sobre os meios de comunicação. Houve grande repercussão na imprensa e chegou-se a falar na volta da censura prévia. O projeto foi retirado de pauta antes da votação.

Desde 2002, pesquisamos a censura junto ao Arquivo Miroel Silveira, sob guarda da Biblioteca da Escola de Comunicações e Artes da USP ${ }^{3}$. Com este artigo, pretendemos contribuir para essa discussão com o que já foi revelado em nossa pesquisa a respeito de como se realizava a censura quando ela estava a cargo de um órgão oficial do Estado.

\section{O ARQUIVO MIROEL SILVEIRA}

Miroel Silveira nasceu em Santos, no Estado de São Paulo, no ano de 1914, em meio a uma família de escritores. Filho de Valdomiro Silveira e primo de Dinah Silveira de Queiroz, foi escritor, poeta, tradutor, crítico literário, diretor e professor de teatro. Pertenceu a inúmeras associações de profissionais de teatro, ganhou prêmios como escritor e atuou em diversas áreas da cultura. Nessa vasta carreira ligada às artes cênicas e à universidade, ele esteve por diversas vezes em contato com o Departamento de Diversões Públicas do Estado de São Paulo, para onde eram encaminhadas as peças para censura prévia dos textos e liberação para apresentação pública. Assim conheceu o imenso acervo de obras que estavam ali reunidas desde a criação do órgão, na época do Estado Novo de Getúlio Vargas, quando integrava o Departamento de Imprensa e Propaganda, extinto na década de 1940. Foi, em parte, com base nesse acervo que ele realizou a pesquisa que deu origem ao seu doutorado, A comédia de costumes: período italo-brasileiro. Subsídio para o estudo da contribuição italiana ao nosso teatro ${ }^{4}$.

Sabendo da importância dessa documentação, Miroel Silveira conseguiu salvá-la da destruição quando, em 1988, colocou-se um ponto final na censura à arte e aos meios de comunicação no Brasil. Não se sabe se por iniciativa do próprio órgão ou de Miroel, esse acervo de peças e documentos chegou a suas mãos. Após sua morte, foi entregue à Biblioteca da Escola de Comunicações e Artes da USP, constituindo o Arquivo Miroel Silveira.
3. Mais informações sobre - Arquivo Miroel Silveira e seus documentos, acessar o endereço www.eca.usp. br/ams.

4. Essa tese foi publicada sob o título A contribuição italiana ao teatro brasileiro. São Paulo/Brasília: Quiron/Instituto Nacional do Livro, 1976. 


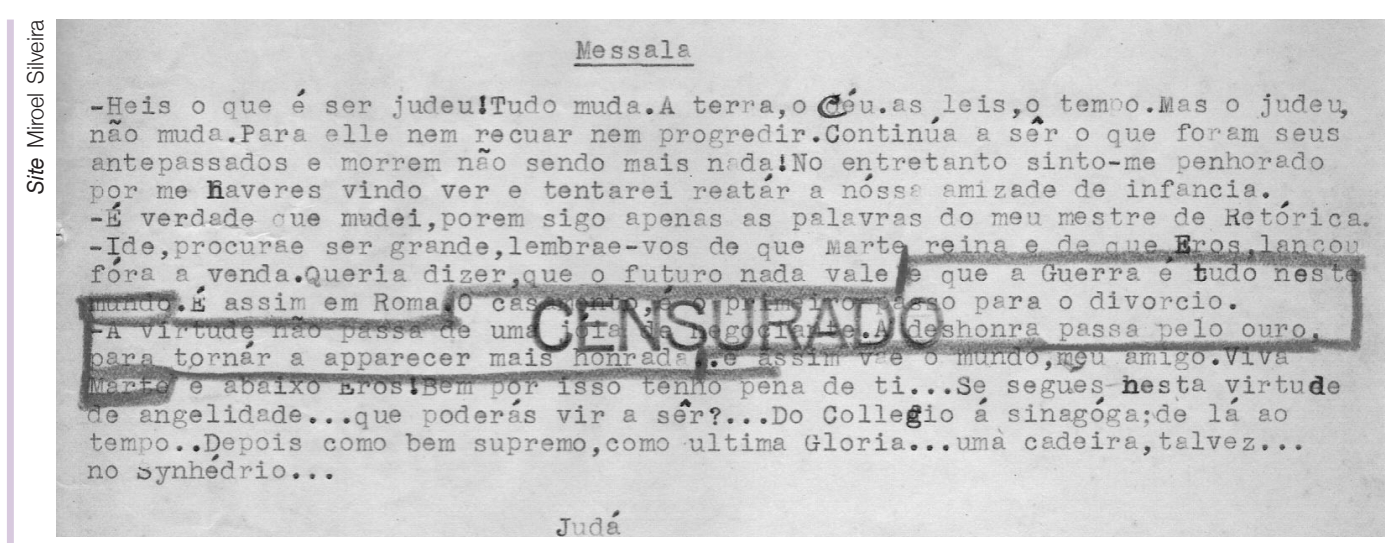

A partir do Arquivo Miroel Silveira, um grupo de pesquisadores passou a estudar o teatro em São Paulo e a censura. Dois projetos de pesquisa já foram elaborados com esse fim.

Trata-se de uma coleção de 6.137 processos de liberação de peças teatrais de apresentação pública, encaminhadas à Divisão de Censura do Departamento de Diversões Públicas do Estado de São Paulo, entre os anos 1930 e 1970, com todos os pareceres, carimbos, vetos e cortes dos censores, além dos originais das peças que deveriam ser encenadas, muitas delas ainda inéditas.

Na condição de presidente da Comissão de Biblioteca da Escola de Comunicações e Artes da Universidade de São Paulo, esta autora entrou em contato com o Arquivo Miroel Silveira, ainda intacto, e pôde reunir um grupo de pesquisadores para estudar o teatro em São Paulo e a censura. Dois projetos de pesquisa foram elaborados com esse fim - o primeiro intitulava-se A censura em cena: organização e análise dos processos de censura teatral do Serviço de Censura do Departamento de Diversões Públicas do Estado de São Paulo, e durou de 2002 a $2005^{5}$. O segundo é o projeto temático A cena paulista: estudo da produção cultural de São Paulo de 1930 a 1970 a partir do Arquivo Miroel Silveira ${ }^{6}$. Iniciado em 2005, deve-se estender até 2009, com apoio da Fapesp, CNPq e USP. Com uma metodologia interdisciplinar que envolve ciências da informação, ciências da comunicação, história, sociologia e arquivística, procuramos reconstituir a história do teatro paulista, analisando a interferência da censura nessa produção.

5. Projeto financiado pela Fapesp, processo 02/07057-3.

6. Projeto financiado pela Fapesp, processo 04/14034-5.
O Arquivo Miroel Silveira, sob custódia da Biblioteca da ECA, é responsável por conservar e estudar mais de seis mil originados do Serviço de Censura do Estado de São Paulo (DDP-SP), através de uma metodologia interdisciplinar. processos de censura prévia ao teatro, Departamento de Diversões Públicas do

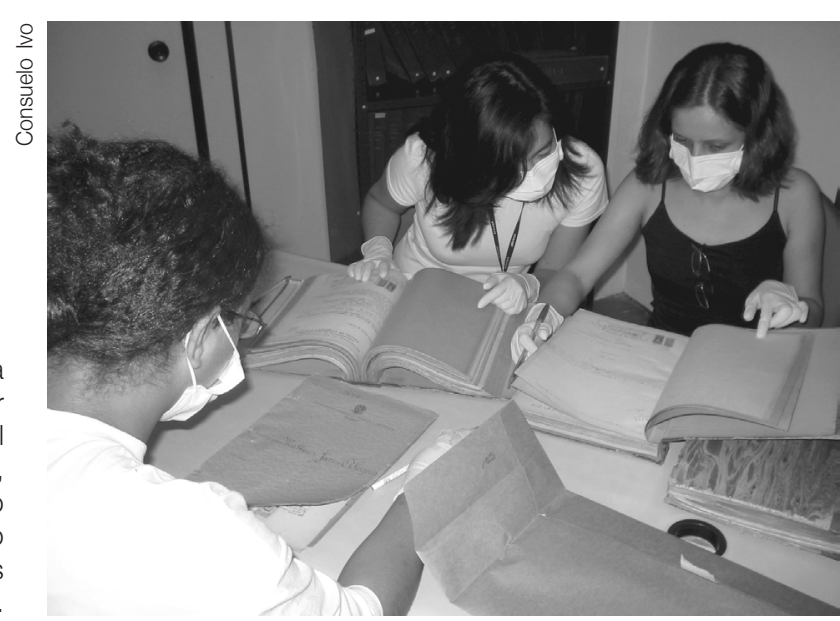




\section{QUEM ERAM OS CENSORES}

Nossa metodologia de trabalho inclui organização e análise documental, registro de informações, pesquisa bibliográfica e entrevistas. Foi através deste último recurso que pudemos conhecer alguns poucos censores ainda vivos que aceitaram dar-nos testemunhos de sua função. $\mathrm{O}$ que conseguimos apreender dessas entrevistas, assim como de pesquisas em outras bases de dados e em fontes bibliográficas, é que a maioria deles ocupou o cargo de censor ou desenvolveu essa atividade não por mérito ou reconhecido saber sobre teatro, educação ou psicologia, mas por serem parentes e amigos de políticos influentes. Esses censores viam com bons olhos o trabalho de censura, sendo uma boa oportunidade de complementação salarial - a tarefa era leve (leitura de, no máximo, um processo por semana), representava certo lustro intelectual, oferecia boa remuneração e não exigia a permanência no Departamento ao longo do dia. Bastava comparecer semanalmente para retirar o processo a ele destinado e que o examinasse onde melhor o aprouvesse. Assim, com a ajuda de parentes e amigos eram indicados censores, podendo também desenvolver outra atividade profissional que, na maioria dos casos, nada tinha a ver com o teatro.

Havia outras regalias - depois da leitura e das intervenções no texto, que assim era devolvido ao autor, o censor assistia ao ensaio geral das peças para averiguar se as indicações eram respeitadas: omissão de palavras e frases, proibição de personagens com vestes de padre ou militar, ou o aumento no comprimento dos maiôs das coristas. Nesse ensaio, realizado às vésperas da estréia, a companhia apresentava o espetáculo só para os censores, ocasião em que eles conheciam pessoalmente os artistas, alguns famosos como Procópio Ferreira e Luz Del Fuego, como nos contou o censor Hamleto Capriglione. Eram bem tratados pelos artistas e consideravam esse ensaio uma ocasião especial. Além disso, caso quisessem assistir novamente ao espetáculo, levando companhia, dois lugares eram reservados especialmente para eles. A entrada era gratuita, claro!

Mesmo sem formação específica que lhes garantisse competência para o trabalho, os censores não recebiam orientação nem treinamento - transmitiamlhes uma série de recomendações que já faziam parte do senso comum, tais como cortar palavrões, qualquer menção a autoridades civis, cenas de sexo e críticas ao governo, independentemente de qual fosse.

\section{QUAIS ERAM AS RESTRIÇÕES E CORTES}

Os cortes obedeciam a quatro diferentes preocupações - primeiramente as de ordem religiosa, levando a se eliminar qualquer menção a Deus e aos santos católicos, assim como ao Papa, ao Vaticano e aos padres e cardeais. Batinas eram proibidas no figurino das peças e, para se ter uma idéia do arbítrio a que se chegava, a palavra semana santa foi cortada da adaptação de uma peça 
7. DDP 0108. Don César de Bazan. Dumanoire e Adolph d'Nery, adaptação de Júlio Ozon, 1942.

8. DDP 0126. Nós os carecas. Chic Chic, pseudônimo de Otelo Queirolo, 1942

9. COSTA, Cristina. Censura em cena. São Paulo: Fapesp/Edusp/Imprensa Oficial, 2006. p. 237.

10. DDP 0216. Morte civil. Paulo Giacometti, tradução de Eduardo Victorino, 1943

11. CARDOSO, Luiz Fernando. Em nome da rosa: um estudo da censura religiosa a partir dos processos de censura prévia ao teatro paulista pertencentes ao Arquivo Miroel Silveira da Biblioteca da ECA/USP - Relatório Final, 2007.

12. ALGRANTI, Leila Mezan. Livros de devoção, atos de censura. São Paulo: Hucitec/Fapesp, 2004

13. DDP 0268, BenHur. Hilário de Almeida, 1938. francesa de título Don César de Bazan ${ }^{7}$, assim como a referência a São Benedito foi retirada da comédia Nós os carecas $^{8}$, que seria encenada no Circo-teatro Queirolo ${ }^{9}$. A menção ao Concílio de Trento, existente na peça Morte civil ${ }^{10}$, de Paulo Giacometti, também foi vetada. Por outro lado, não era permitido citar outras religiões, especialmente as de origem africana.

Um de nossos pesquisadores, Luiz Fernando Cardoso, buscou estudar especificamente a censura religiosa, que se justificava no que os censores entendiam como sendo a defesa da Igreja Católica e de sua doutrina. Em seu relatório, Cardoso afirma que pelo menos dez por cento de toda a intervenção dos censores nas peças, que deveriam ser encenadas na primeira metade do século XX, obedeciam a critérios religiosos. O maior número de cortes recaiu sobre a palavra Deus, não importando se a fala fosse uma referência explícita à divindade ou apenas uma expressão idiomática sem maior importância. Também não eram permitidos anjos do céu e, nem mesmo, os diabos ${ }^{11}$.

Leila Mezan Algranti ${ }^{12}$, estudando a censura em Portugal e no Brasil, especialmente no período colonial, diz que na Igreja Católica está a origem da censura ibérica. Só mais tarde ela divide com o imperador o direito de censurar livros e decidir o que se podia escrever ou ler na metrópole e na colônia. $\mathrm{O}$ Arquivo Miroel Silveira guarda os resquícios desse passado.

Outra preocupação dos censores era com abusos de ordem moral e, em nome deles, cortavam palavras como amante, a campeã de vetos. Palavrões eram igualmente um dos principais alvos da censura, que também não deixava ir ao palco palavras mais inofensivas como chato e chatice, por serem consideradas de apelo sexual. Dizer que toda mulher tem seu preço era considerado atentatório aos bons costumes, mesmo que estivesse na fala do personagem de uma peça intitulada $O$ sina-da-cruz, de autoria de Francisco Colman. A frase $O$ casamento é o primeiro passo para o divórcio foi proibida na adaptação feita por Hilário de Almeida ao épico romance histórico Ben-Hur ${ }^{13}$.

Brasil também era palavra ilícita, pois a censura julgava que assim protegia a pátria de situações constrangedoras. Nomes próprios como Getúlio eram vetados mesmo sendo apenas a denominação de um figurante. Personagens com nome russo eram proibidos por, de alguma forma, fazerem referência à ex-União Soviética e ao comunismo, outra grande preocupação dos censores. Palavras como ditador e presidente igualmente faziam parte da lista de cortes, assim como qualquer menção às forças armadas. Da mesma forma, as batinas e os uniformes militares não eram permitidos para os personagens. Consideramos que esses critérios são de natureza política, assim como a palavra Roma e romanos, censuradas na peça Ben-Hur, da qual já falamos. A época era difícil - em meio à Segunda Guerra Mundial -, e Getúlio Vargas passara a apoiar os aliados. Não ficava bem que, em palcos brasileiros, uma peça exaltasse Roma, a capital da Itália fascista contra a qual o Brasil lutaria em breve. Não importava que a peça se situasse na Antiguidade.

De natureza social eram os cortes que procuravam extrair das peças a menção a conflitos entre grupos e classes sociais. Judeu e negro eram vetados, 
assim como outros relatos sobre grupos étnicos e religiosos. A palavra Bom Retiro, bairro tradicional de judeus na cidade de São Paulo, foi removida de uma peça de teatro de revista intitulada Boite russa ${ }^{14}$.

Como podemos perceber, os critérios são oportunistas, superficiais e manifestam uma visão estereotipada das artes, dos conflitos sociais e do público, considerado sempre incapaz de escolher o que era melhor para si e desprotegido diante das intenções malévolas dos dramaturgos. Com esses exemplos, é possível notar que a censura protege, na verdade, o poder instituído, político, religioso ou econômico, que percebe em qualquer atitude crítica ou contestadora uma ameaça.

\section{QUEM ERAM OS AUTORES CENSURADOS}

Os autores vítimas de maior perseguição por parte dos censores eram os nacionais. Apesar de haver, nesse período, um grande fluxo de imigrantes responsáveis pelo desenvolvimento de grupos filodramáticos e de encenações de peças em idioma estrangeiro, a censura pouco agia contra eles. Tradutores juramentados faziam uma sinopse em português para a apreciação dos censores, que liberavam as apresentações. Como os censores, em sua maioria, não dominavam o árabe, iídiche, lituano ou polonês, idioma de muitas peças pertencentes ao Arquivo Miroel Silveira, acabavam por fazer vistas grossas, deixando apresentar esses textos que se destinavam ao restrito grupo de imigrantes que dominavam a língua. A atenção recaía toda para as peças em português, escritas, adaptadas ou traduzidas por brasileiros e portugueses.

Dentre esses, os que mereciam uma leitura mais atenta eram os autores populares, responsáveis pelo teatro de revista e pelo circo-teatro ${ }^{15}$ - circos estes que, além de números de malabarismo, comicidade e adestramento, exibiam pequenas encenações teatrais. Os circos-teatro foram responsáveis, na primeira metade do século XX, pela divulgação da cultura e das apresentações teatrais nas cidades do interior de São Paulo, nas quais não chegava o cinema, e mais tarde, nem a televisão. Mas não sendo, em sua maioria, artistas de renome, por terem uma estrutura mambembe, serem itinerantes e voltados à comicidade e à sátira, eram vistos com desconfiança. As companhias profissionais de teatro eram mais respeitadas pelos censores, assim como artistas consagrados da importância de um Paulo Autran.

Além de uma censura mais dura para com os chamados artistas populares, o estudo dos processos do Arquivo Miroel Silveira revela que os autores mais críticos e que encaravam o teatro como forma de conscientização do público, assim como os grandes inovadores das artes cênicas, transformavam-se em alvos preferenciais do lápis vermelho usado pelos censores para intervir nos textos. Dias Gomes, Plínio Marcos e Nelson Rodrigues demoraram até dez anos para ver algumas de suas peças encenadas no palco. "Como meu nome era sistematicamente recusado, resolvi criar autores-fantasmas, em nome dos quais escrevia"16, afirma Dias Gomes em sua biografia. Outro recurso dos autores no drible da
14. DDP 0385. Don César de Bazan. Jean Cocquelin, 1943.

15. COSTA, Cristina. Comunicação e censura: o circo-teatro na produção cultural paulista de 1930 a 1970. São Paulo: Terceira Margem, 2006.

16. GOMES, Dias. Apenas um subversivo. Rio de Janeiro: Bertrand Brasil, 1998. p. 147. 
17. MULLER, Heiner. Guerra sem batalha. São Paulo: Editora Liberdade, 1997. p. 154.

18. KILPP, Suzana. Os cacos do teatro. Porto Alegre: Unidade Editorial, 1996.

* Ver PALLOTTINI, Renata. Que sabemos nós de nós mesmos? Comunicação \& Educação, São Paulo: CCA-ECA-USP/Paulinas, n. 2, p. 91-96, maio/ago. 2007. (N.E.) censura era trocar o título da peça e reapresentá-la para o Departamento de Diversões Públicas. Algumas vezes obtinham sucesso, o que denota critérios não muito científicos da censura.

Heiner Muller, dramaturgo alemão e autor do livro Guerra sem batalhas: uma vida entre duas ditaduras, conta em seu livro como o autoritarismo e a censura obrigavam os artistas a utilizar subterfúgios como jogo de influência, jogo de palavras, pseudônimos e desculpas, para não serem reduzidos ao silêncio. "É o maneirismo que nasce da covardia" ${ }^{17}$, diz ele.

Outras alternativas contra o arrocho da censura eram as performances e as improvisações, que se transformavam em uma forma peculiar de a arte sobreviver ao controle e ao autoritarismo ${ }^{18}$. Dercy Gonçalves era mestra no improviso e garante que sempre disse tudo o que quis.

\section{AS CONSEQÜÊNCIAS QUE A CENSURA TROUXE PARA A ARTE}

Que conseqüências teve todo esse esforço de controle sobre a produção artística, tendo como suposto objetivo a defesa da sociedade e do público? O teatro se tornou mais educativo e o público mais apaixonado por teatro? O que nossas pesquisas têm revelado é que os mecanismos de censura baseados no poder de decidir se um espetáculo seria encenado ou não, ou como chegaria ao público, ofereceu apenas margem a perseguições políticas, ao estabelecimento de relações menos transparentes entre artista e Estado, a um teatro que faz concessões e a uma tendência muito perversa que é a autocensura.

Muitos jovens que atuavam em teatro amador ou teatro estudantil, procurando desenvolver seus talentos, intimidados e inibidos, acabaram abandonando o caminho da arte. Alguns autores se exilaram, pelo menos durante certo tempo, fugindo a uma perseguição que podia levá-los à prisão ou à derrocada financeira, pois os espetáculos eram proibidos nas vésperas das estréias, quando muitos investimentos haviam sido feitos nos ensaios, no aluguel das salas de espetáculo, nos cenários e figurinos. Vários textos não foram encenados e até hoje permanecem desconhecidos, pois estavam calcados em sua época e em sua história. Diversos jovens deixaram de ver espetáculos que falavam deles e do momento que estavam vivenciando. E o teatro paulista, que vivia uma de suas fases mais vigorosas, foi perdendo a força e sucumbindo ao poder da censura*.

\section{VOLTANDO AO INÍCIO}

Nem tudo que analisamos aqui, entretanto, pode ser diretamente relacionado com os incidentes recentes que descrevemos na introdução deste texto. A censura prévia ao teatro feita pelo Estado não existe mais no Brasil, desde 1988, quando a constituição oficialmente a aboliu. Os principais alvos dela, hoje, são os meios de comunicação de massa e a internet, que globalizou a discussão sobre 
o que pode ou não circular pelo mundo. Mas, ao lado dessas diferenças, a tradição censória permanece. Indivíduos, grupos ou instituições que desejam evitar qualquer crítica, que consideram seus interesses mais importantes que o direito da sociedade à informação e ao conhecimento, ainda recorrem ao Estado para defendê-los, seja através de órgãos fiscalizadores do Poder Executivo, seja mediante processos judiciais. Aqueles que julgam que uma doutrina vale mais do que qualquer outra, simplesmente porque acreditam nela, continuam considerando como sacrilégio qualquer manifestação que a ela se oponha. A dificuldade em lidar com a diferença, com o conflito, com o questionamento e com a crítica, ainda leva o público em geral a desejar que o Estado interfira, evitando a oposição, o confronto e o saudável exercício de avaliar e julgar por si mesmo.

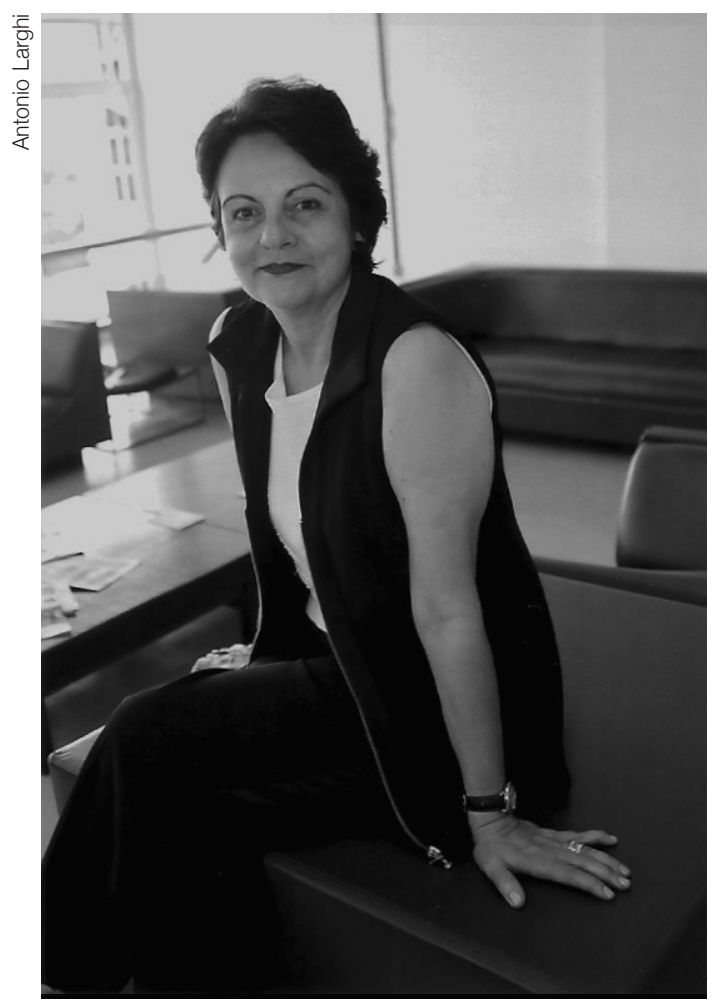

Através do Arquivo Miroel Silveira, ainda intacto, Cristina Costa pôde reunir um grupo de pesquisadores para estudar o teatro em São Paulo e a censura. Dois projetos de pesquisa foram elaborados com esse fim - o primeiro foi concluído em 2005 e o segundo deve-se estender até 2009, com apoio da Fapesp, CNPq e USP.

Não estamos aqui defendendo que as manifestações artísticas e os meios de comunicação de massa tenham liberdade para usar de todos os recursos para obter audiência e fluência de público, nem que possam alimentar o desejo do leitor ou ouvinte por violência, por escárnio ou pela invasão da vida alheia. O que defendemos, a partir dos arbítrios que detectamos nos atos dos órgãos de censura, é que a única medida realmente eficaz para combater abusos é a educação do público, o julgamento e o exercício da cidadania para rejeitar e recusar aquilo que se considera pernicioso ou abusivo.

A constituição de diversos países coloca à disposição dos cidadãos meios para reclamar por seus direitos e para punir aqueles que caluniem ou difamem pessoas, grupos ou instituições. Quanto mais usarmos estes meios, melhor eles 
19. DARNTON, Robert. Os best-sellers proibidos da França pré-revolucionária. São Paulo: Companhia das Letras, 1998. p. 19. funcionarão. Não se trata, entretanto, de transformar juízes em censores, mas em instrumentos capazes de apurar a credibilidade daquilo que é veiculado publicamente pelos meios de comunicação e de fazê-los responder pelas conseqüências dessa divulgação. A solução, portanto, para abusos é o cumprimento da lei, a educação e o exercício da cidadania, e não a transferência dos nossos direitos e nossas responsabilidades a órgãos públicos que, como o Arquivo Miroel Silveira tem comprovado, passam décadas praticando arbitrariedades cujas conseqüências são somente o desestímulo à crítica e à criatividade.

\section{CENSURA NÃO É EDUCAÇÃO}

Para terminar, gostaria de falar mais diretamente com o professor, sempre tão preocupado com aquilo que a mídia transmite e com os erros e abusos que ela comete no dia-a-dia. Nossa pesquisa tem demonstrado que a censura não educa, mas acabrunha, produz injustiças, reafirma estereótipos e trabalha a favor do poder instituído, da religião dominante e do preconceito. $\mathrm{O}$ teatro brasileiro só deveu à censura a perda de espaço para a televisão, que contratou autores, atores e diretores que não conseguiam mais encenar suas peças. De resto, perdemos textos que não foram assistidos, dramaturgos que desistiram do teatro e atores que foram trabalhar no exterior. Nenhuma educação resultou desse processo que durou décadas.

Portanto, a censura não educa, mas a educação, esta sim, pode formar um público exigente e rigoroso capaz de desligar a televisão quando ela estiver exibindo programas de má qualidade, de não assistir a filmes cujos valores sejam duvidosos, de deixar nas prateleiras livros com teorias ou informações não fundamentadas. Por isso defendemos tanto que a arte e os meios de comunicação sejam objetos precípuos da educação formal e informal.

$\mathrm{E}$, se os argumentos aqui expostos não convenceram nosso leitor, resta dizer que a proibição de livros e filmes provoca curiosidade e alimenta sua circulação ilegal. A biografia de Roberto Carlos transitou pela internet mesmo depois de proibida, e as charges de Maomé tiveram várias reedições em alguns veículos mais corajosos.

Robert Darnton, estudando a circulação ilegal de livros proibidos na França no século XVIII, explica por que a queima de livros procurava ser discreta, sem o sensacionalismo de outras formas de repressão:

Sabendo que nada promovia melhor as vendas do que uma boa fogueira, preferiam livros, e aprisionar (as autoridades); apreender livreiros com o mínimo possível de estardalhaço... enquanto essas obras ardiam em chamas, milhares de outras circulavam secretamente pelos canais do comércio clandestino ${ }^{19}$.

Por tudo que aqui expomos, defendemos que o público seja tratado como cidadão, que se preserve o seu direito à informação e que se acredite na sua capacidade de, como receptor, escolher entre o bem e o mal e comer da árvore da sabedoria. A educação tem muito a contribuir nesse sentido. 


\section{REFERÊNCIAS BIBLIOGRÁFICAS}

ALGRANTI, Leila Mezan. Livros de devoção, atos de censura. São Paulo: Hucitec, Fapesp, 2004.

ANDREUCCI, Álvaro Gonçalves Antunes; OLIVEIRA, Valéria Garcia de. Cultura amordaçada: intelectuais e músicos sob a vigilância do DEOPS. São Paulo: Arquivo do Estado/Imprensa Oficial, 2002.

AQUINO, Maria Aparecida de. Censura, imprensa, estado autoritário. Bauru (SP): Edusc, 1999.

CASTRO, Ruy. O anjo pornográfico. São Paulo: Companhia das Letras, 1992.

COSTA, Cristina. Censura em cena. São Paulo: Fapesp/Edusp, Imprensa Oficial, 2006.

DARNTON, Robert. Os best-sellers proibidos da França pré-revolucionária. São Paulo: Companhia das Letras, 1998.

GOMES, Dias. Apenas um subversivo. Rio de Janeiro: Bertrand Brasil, 1998.

KILPP, Suzana. Os cacos do teatro. Porto Alegre: Unidade Editorial, 1996.

MULLER, Heiner. Guerra sem batalha. São Paulo: Ed. Liberdade, 1997.

SOUZA, José Inácio de Melo. O estado contra os meios de comunicação. São Paulo: Annablume/Fapesp, 2003. 